\title{
Emergency Periodicity and Seeds Bank of Weeds in Systems of Tillage and No Tillage
}

\author{
André Luiz de Souza Lacerda ${ }^{1}{ }^{*}$, Ricardo Filho Victoria ${ }^{1}$, Cristiane Gonçalves de Mendonça ${ }^{2}$ \\ ${ }^{1}$ Departament of Vegetable Production, São Paulo of University, Piracicaba, Brazil \\ ${ }^{2}$ Agronomy Faculty, Mato Grosso do Sul University, Aquidauana, Brazil
}

Email address:

alslacer@yahoo.com.br (A. L. de S. Lacerda)

${ }^{*}$ Corresponding author

\section{To cite this article:}

André Luiz de Souza Lacerda, Ricardo Filho Victoria, Cristiane Gonçalves de Mendonça. Emergency Periodicity and Seeds Bank of Weeds in Systems of Tillage and No Tillage. Plant. Vol. 7, No. 3, 2019, pp. 54-61. doi: 10.11648/j.plant.20190703.15

Received: July 19, 2019; Accepted: August 28, 2019; Published: September 10, 2019

\begin{abstract}
In Brazil there is lack of information about the weed emergency periodicity from the seed bank in the soil. This information is important to the elaboration of a strategy of weeds management. The objective of this research was to evaluate emergency periodicity of weeds by a frequent application of glyphosate used to determine the seeds bank in two systems of handling of the soil (tillage and no tillage). The experiment was conducted in the district of Piracicaba-SP, during two years, on the Dept. of Vegetable Production of ESALQ/USP. The experimental design was of completely randomized blocks with subdivided portions, repeated four times. The treatment consisted in glyphosate applications rates of $0,540,720,900,1080$, 1260 and 1440 g.i.a ha ${ }^{-1}$. Weeds were sampled through the method of iron square and the seeds bank was determined by withdrawing of soil in depths of 0-2.5, 2.5-5.0, 5.0-10.0, 10.0-15.0 and 15.0-20.0 $\mathrm{cm}$. The herbicide glyphosate was shown effective in controlling weeds. In the year of 2001, they happened periodicitys of emergency more differentiated in the no tillage that in the tillage, but in the year of 2002, those differences of periodicitys in the species were not as expressive. The seeds concentrated layer superficial of the soil, in the no tillage system, while the tillage preparation in the soil distributed the seeds in the profile of soil.
\end{abstract}

Keywords: Glyphosate, Richardia Brasilensis, Digitaria Insularis, Soil Depth, Seeds Bank

\section{Introduction}

Weeds are characterized by producing lots of seeds when in a constantly disturbed environment that is due to the fact that only a small percentage germinates and survives completing its life cycle. The great amount of seeds produced by a single plant is sufficient to maintain or increase the population, and to maintain a seed bank appropriate for occurring dissemination and colonization of new areas.

The seed bank is a reserve of viable seeds in soil, on the surface or at depth. This reserve is constituted as the initial stage of a reproductive life cycle for annual species, is also the main cause for their persistence. In agricultural areas the seed bank in soil has been widely studied because of its importance. It is used to study the quantitative relations between the population of weeds and the infested flora. This kind of information allows to develop predictive indices and to formulate emergency models, making it possible to predict future infestations and how adequate soil management, measures and culture should be.

When using plow, seeds tends to better distribute along the ground, while with till or shallow tillage the concentration happens to be near the surface [6]. Found that with a notillage system, over $60 \%$ of all weed seeds, among the total seed bank, were found up to $1 \mathrm{~cm}$ deep and few were found at a depth below $10 \mathrm{~cm} \mathrm{[1].}$

Found through studies that seeds distribution in the soil, both when carried out with minimum tillage or no tillage, have the same concentrations at $2.5 \mathrm{~cm}$ deep. The conventional system, however, distributes the seeds up to 20 cm depth [7].

Mentions that the mulch is an important factor in the seed bank behavior. According to the author, this would influence weeds under physical (light), biological (microbiocenose) and chemical (allelopathy) aspects [9]. 
According to, reducing the causes of disturbance in the soil, resulting from the adoption of no-till method, causes a temporary reduction in the population of weeds [9]. The main factor is the large stock of ground seeds that is kept at a sufficient depth so there is no germination and seedling emergence. Seeds produced after the adoption of a no-till method would be deposited in the surface layer of soil, becoming more susceptible to the action of large predators such as birds and rodents.

After evaluating the size of the seed bank in different cropping systems, concluded that as many seeds found in notill system [2]. In general, one can say that interactions between herbicides, tillage and cultivation practices alter the size and nature of the seed bank [10].

This survey was conducted in order to assess the emergency flow of weeds, determining the seed bank at different depths. The rates of application of a glyphosate herbicide and direct and conventional sowing system were used.

\section{Materials and Methods}

The research was conducted during the months of January 2001 to December 2002, inside the Department of Plant Production of ESALQ - College of Agriculture "Luiz de Queiroz", located in Piracicaba - SP, present at geographical coordinates: $22^{\circ} 42^{\prime} 9^{\prime \prime}$ 'South latitude and 47 $38^{\prime} 30^{\prime \prime}$ 'West longitude approximately 540 meters. Precipitation and average temperatures of the months January 2001 to December 2002 are shown in Figures 1 and 2. The data was collected in a weather station of the Department of Physics and Meteorology of the ESALQ/USP, which is close to the experimental area.

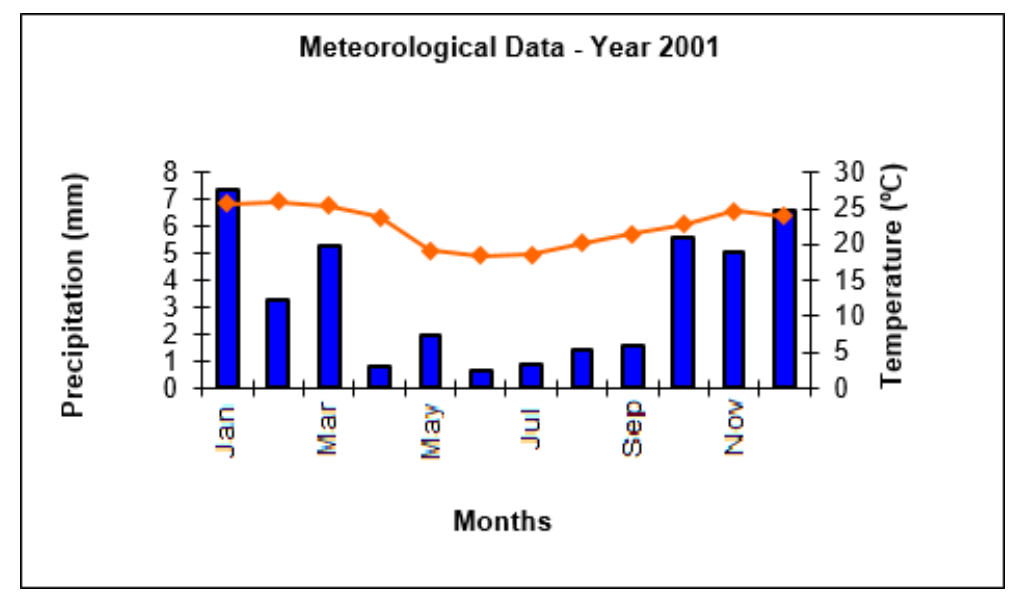

Figure 1. Data on rainfall $(\mathrm{mm})$ and average temperature $\left({ }^{\circ} \mathrm{C}\right)$ occurred in the period from January to December 2001, Piracicaba-SP.

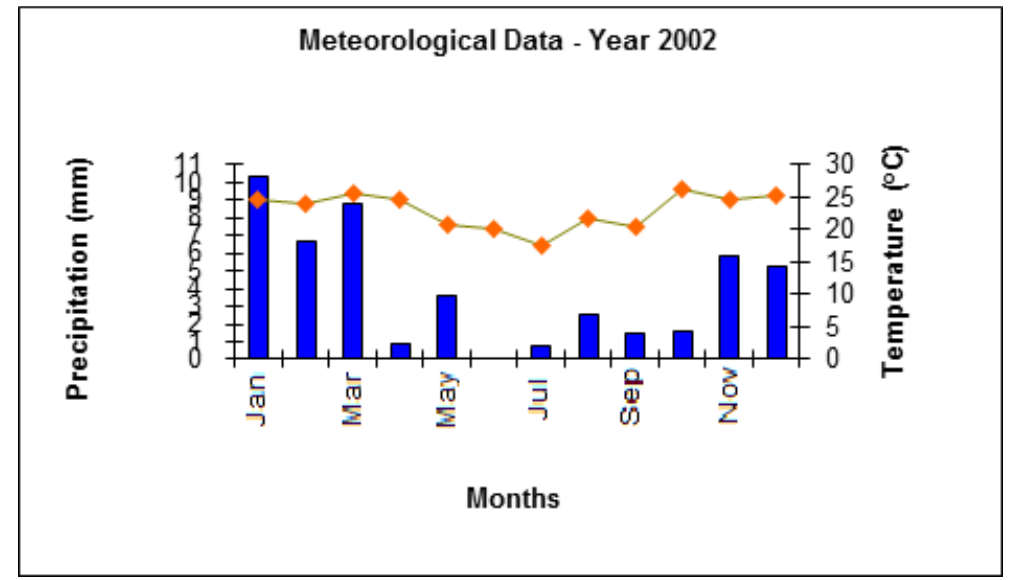

Figure 2. Data on rainfall $(\mathrm{mm})$ and average temperature $\left({ }^{\circ} \mathrm{C}\right)$ occurred in the period from January to December 2002, Piracicaba-SP.

Applications were carried out using a backpack sprayer with constant pressure of $279.3 \mathrm{kPa}$, Nozzle XR Teejet 110.02, spray volume $300 \mathrm{~L} \mathrm{ha}^{-1}$, in the absence of wind and always in the morning. It was considered as a witness to the parts which have not undergone application of glyphosate, being cut out when applied. Survey and determination of flora were made with an iron square, size $0.5 \times 1.0 \mathrm{~m}$, in direct and conventional planting systems. It was launched randomly within the floor area of the subplots, 15 days before the application of glyphosate was made to identify and count the species of weeds.

Soil samples were made with an iron auger of $3.14 \mathrm{~cm}$ in diameter placed at depths of 0.0 to $2.5 ; 2.5-5.0 ; 5.0-10.0$; 10.0-15.0 cm and from 15.0 to 20.0. Each composite sample consisted of 20 simple soil samples per subplot, which were placed in plastic bags marked with their depths and 
transported for evaluations, after dried to achieve a constant weight. Also were taken subsamples from the seed bank for chemical and physical analyzes in the Soil and Nutrition
Laboratory of Plant ESALQ/USP, as shown in Tables 1 and 2 , respectively.

Table 1. Results of chemical analyzes of soil experimental site-Piracicaba.

\begin{tabular}{|c|c|c|c|c|c|c|c|c|c|c|c|}
\hline Depht & pH & M. O. & $\mathbf{P}$ & $\mathbf{S}$ & $\mathbf{K}$ & $\mathrm{Ca}$ & Mg & $\mathrm{H}+\mathrm{Al}$ & SB & $\mathbf{T}$ & $\mathbf{V}$ \\
\hline (cm) & $\mathrm{CaCl}^{2}$ & $\mathrm{~g} \mathrm{dm}^{-3}$ & $\mathrm{mg} \mathrm{dm}^{-3}$ & & Mn & & & & & & $\%$ \\
\hline $0-2.5$ & 5.1 & 26 & 7 & 69 & 4.1 & 44 & 12 & 34 & 60.1 & 94.1 & 64 \\
\hline $2.5-5.0$ & 5.1 & 26 & 8 & 81 & 3.9 & 46 & 14 & 31 & 63.9 & 94.9 & 67 \\
\hline $5.0-10.0$ & 5.0 & 22 & 6 & 72 & 3.0 & 37 & 12 & 31 & 52.0 & 83.0 & 63 \\
\hline $10.0-15.0$ & 4.9 & 21 & 9 & 136 & 2.8 & 35 & 12 & 34 & 49.8 & 83.9 & 59 \\
\hline $15.0-20.0$ & 5.1 & 22 & 6 & 73 & 3.0 & 43 & 13 & 28 & 59.0 & 87.0 & 68 \\
\hline
\end{tabular}

$\mathrm{SB}=$ sum of bases; $\mathrm{T}=$ cation exchange capacity; $\mathrm{V}=$ base saturation; Prof. = Depth; M. O. = Organic matter.

Table 2. Results of physical analyses of soil experimental site - Piracicaba.

\begin{tabular}{lllll}
\hline Depht (cm) & Sandy (\%) & Silt (\%) & Clay (\%) & Classe \\
\hline $0-2.5$ & 49 & 14 & 37 & Clay \\
$2.5-5.0$ & 47 & 12 & 41 & Clay \\
$5.0-10.0$ & 45 & 12 & 43 & Clay \\
$10.0-15.0$ & 43 & 15 & 42 & Clay \\
$15.0-20.0$ & 45 & 15 & 40 & Clay \\
\hline
\end{tabular}

Texture class: up to $14 \%$ clay - sandy; $15-24 \%$ clay - sandy average; $25-34 \%$ clay - media clay; $35-59 \%$ clay - clay; $60 \%$ or more clay - very clayey.

After drying the ground, approximately one kilo per sample was pulled out and wrapped in aluminum trays with dimensions of $20 \times 30$ and $5 \mathrm{~cm}$ high. Then they were randomly placed in stands inside a greenhouse under daily irrigation system. Trays were perforated so that there was no accumulation of water and consequently no rotting of seeds. The identification and counting of emerged weeds were taken at 15,30 and 60 days after implantation of the trays.

Data was transformed to square root of $x+0.5$ and was subjected to analysis of variance and F test, the sanest statistical program. For significant analyzes we compared the means by Tukey test at $5 \%$ probability.

\section{Results and Discussion}

Table 3 presents the average of emerged plants per square meter in different doses, employed in direct and conventional planting systems during the rainy (summer) and dry (winter) seasons in the years of 2001 and 2002. At the beginning, in January 2001, plots were homogeneous because did not contain a significant variability of weeds and, although there was a trend toward fewer weeds per $\mathrm{m}^{-2}$ in larger doses, there was no significant difference between the rates of glyphosate in two consecutive years when applied in the areas of conventional and direct system. Portions receiving no herbicide application had only made up weeding, showing that the herbicide was effective in controlling weeds even in lower doses.

Table 3. Average number of weeds per $m^{-2}$ emerged in glyphosate doses in direct and conventional planting systems, during summer and winter periods in the years 2001 and 2002 .

\begin{tabular}{|c|c|c|c|c|c|c|}
\hline \multirow{2}{*}{ Rate/Systems } & \multicolumn{3}{|l|}{2001} & \multicolumn{3}{|l|}{2002} \\
\hline & Jan & Jun & Nov & Jan & Jun & Nov \\
\hline 0 & $231 \mathrm{a}$ & $143 \mathrm{a}$ & $121 \mathrm{a}$ & $161 \mathrm{a}$ & $32 \mathrm{a}$ & $42 \mathrm{a}$ \\
\hline 540 & $222 \mathrm{a}$ & $7 \mathrm{~b}$ & $27 \mathrm{~b}$ & $70 \mathrm{~b}$ & $7 \mathrm{~b}$ & $15 \mathrm{~b}$ \\
\hline 720 & $359 \mathrm{a}$ & $4 \mathrm{~b}$ & $27 \mathrm{~b}$ & $61 \mathrm{~b}$ & $10 \mathrm{~b}$ & $15 \mathrm{~b}$ \\
\hline 900 & $254 \mathrm{a}$ & $3 \mathrm{~b}$ & $24 \mathrm{~b}$ & $55 \mathrm{~b}$ & $9 \mathrm{~b}$ & $12 \mathrm{~b}$ \\
\hline 1080 & $190 \mathrm{a}$ & $2 b$ & $25 \mathrm{~b}$ & $51 \mathrm{~b}$ & $5 \mathrm{~b}$ & $11 \mathrm{~b}$ \\
\hline 1440 & $259 \mathrm{a}$ & $3 b$ & $18 \mathrm{~b}$ & $36 \mathrm{~b}$ & $3 \mathrm{~b}$ & $13 \mathrm{~b}$ \\
\hline Tillage & $247 \mathrm{a}$ & $14 \mathrm{a}$ & $28 \mathrm{~b}$ & $77 \mathrm{a}$ & $6 \mathrm{~b}$ & $13 \mathrm{~b}$ \\
\hline No tillage & $220 \mathrm{a}$ & $33 \mathrm{a}$ & $48 \mathrm{a}$ & $60 \mathrm{a}$ & $12 \mathrm{a}$ & $21 \mathrm{a}$ \\
\hline \multicolumn{7}{|l|}{ Teste F } \\
\hline Systems (S) & $0.53^{\mathrm{ns}}$ & $3.14^{\mathrm{ns}}$ & $8.49^{* *}$ & $2.09^{\mathrm{ns}}$ & $4.75^{*}$ & $7.12 *$ \\
\hline Rates (D) & $0.18^{\mathrm{ns}}$ & $15.21^{* *}$ & $17.24^{* *}$ & $7.73^{* *}$ & $8.45^{* *}$ & $9.26^{* *}$ \\
\hline \multicolumn{7}{|l|}{ DMS } \\
\hline Systems & 87 & 21 & 13 & 23 & 5 & 5 \\
\hline Rates & 250 & 59 & 38 & 67 & 16 & 17 \\
\hline Overall average & 234 & 23 & 38 & 68 & 9 & 18 \\
\hline C. V. $(\%)$ & 37 & 52 & 34 & 34 & 60 & 36 \\
\hline
\end{tabular}

* Significant difference at $5 \%$ probability by Test $\mathrm{F}$

** Significant difference at $1 \%$ probability by Test $\mathrm{F}$ 
The growth stages of weeds were 2-4 true, leaving up to 1 tiller in dicotiledoneas and monocotiledoneas, respectively. Weed species found in the area using the iron square method are presented in TABLE A1 and A 2.

It was also found that there was an overtime decrease of emerged seedlings in hoed plots treated with herbicides. This reduced the overall average, considering that witness group was 71,61 and $52 \%$ in January, June and November.

The number of weeds in both direct and conventional systems did not differ significantly in January, June 2001 and January 2002, but in November 2001, June and November 2002 there was a significant difference. The tillage system, on the other hand, presented smaller number of emerged seedlings. This was perhaps because of successive herbicide applications that have provided a decrease in the number of the soil seed bank. The disturbance of soil in the conventional system due to the use of the agricultural implements (plow + grade) resulted in reversing layers and seeds positions, thus resulting in a higher number of emerged weeds per $\mathrm{m}^{-2}$ when compared to the direct system. That is because, according to, the proximity to the surface causes higher seed germination and establishment of weeds [1].

In Figures 3 and 4, we find the results of surveys about the total number of weeds, monocotiledoneas and dicotiledoneas per $\mathrm{m}^{-2}$ occurred, from January to December 2001, in direct and conventional sowing system, in the prevailing conditions.

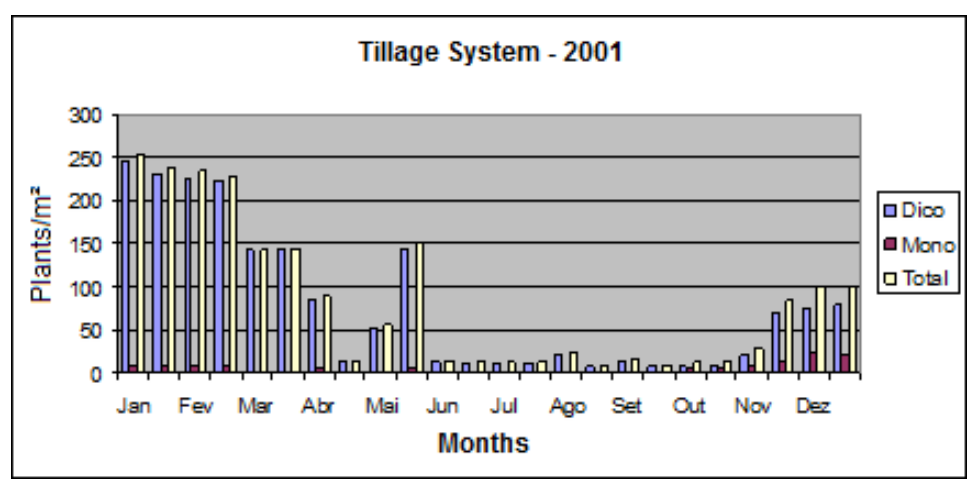

Figure 3. Results of total withdrawal of weeds, monocotiledoneas (mono) and dicotiledoneas (dico) per $m^{-2}$ occurred from January to December 2001 in tillage system.

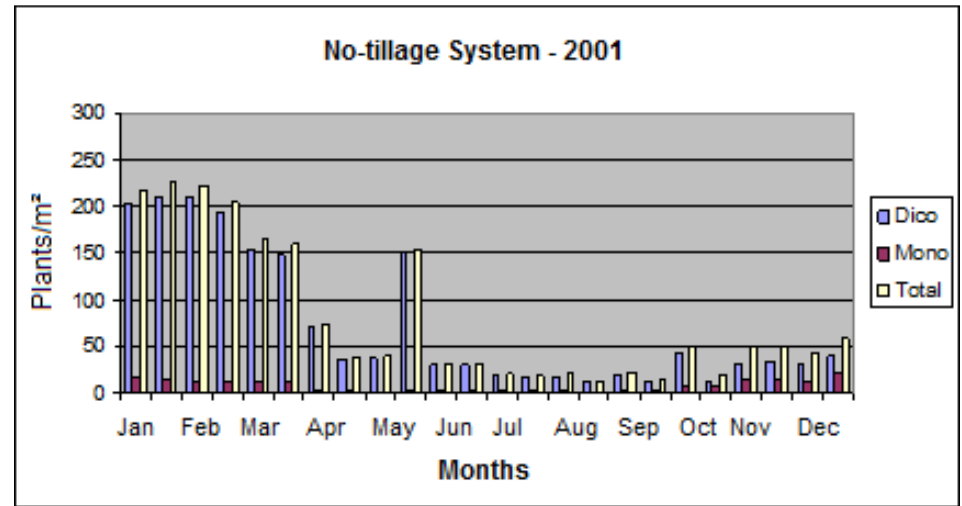

Figure 4. Results of total withdrawals of weeds, monocotiledoneas (mono) and dicotiledonas (dico) per $m^{-2}$ occurred from January to December 2001 in notillage system.

We can see that during the hot and rainy summer period, the number of weeds found in the area is large because of high temperatures and frequent rainfall. As we approached autumn and winter, the flow and number of emerging weeds decrease for both direct and conventional till system. Weather data can be found in Appendices 1-24 where we have precipitation, relative humidity, solar radiation, average temperature, daily minimum and maximum of each month during the period studied.

In May, was recorded an amount of $60.6 \mathrm{~mm}$ of precipitation. Specifically on days 11, 12 and 13 May rained $6.5 ; 2.3$ and $21.7 \mathrm{~mm}$, respectively, which accumulated 30.5 $\mathrm{mm}$ of rain two days before the first counting of weeds and
$22.4 \mathrm{~mm}$ before the second count, as can be seen in Table A3. During a milder weather, with the average temperature of $19.1^{\circ} \mathrm{C}$, there may have been less evapotranspiration giving ideal conditions for emergency flow of weeds, especially for species like the Leucas martinicensis (cord-of-eyed). These species had a higher percentage of emergences in May in relation to others.

In Figures 5 and 6, Richardia brasiliensis and Leucas martinicensis stood out as dominant species during 2001. Both had emergency flows from February to August. In the beginning of October there was a better balance in the percentage of seedling emergence among all species observed in the area. 


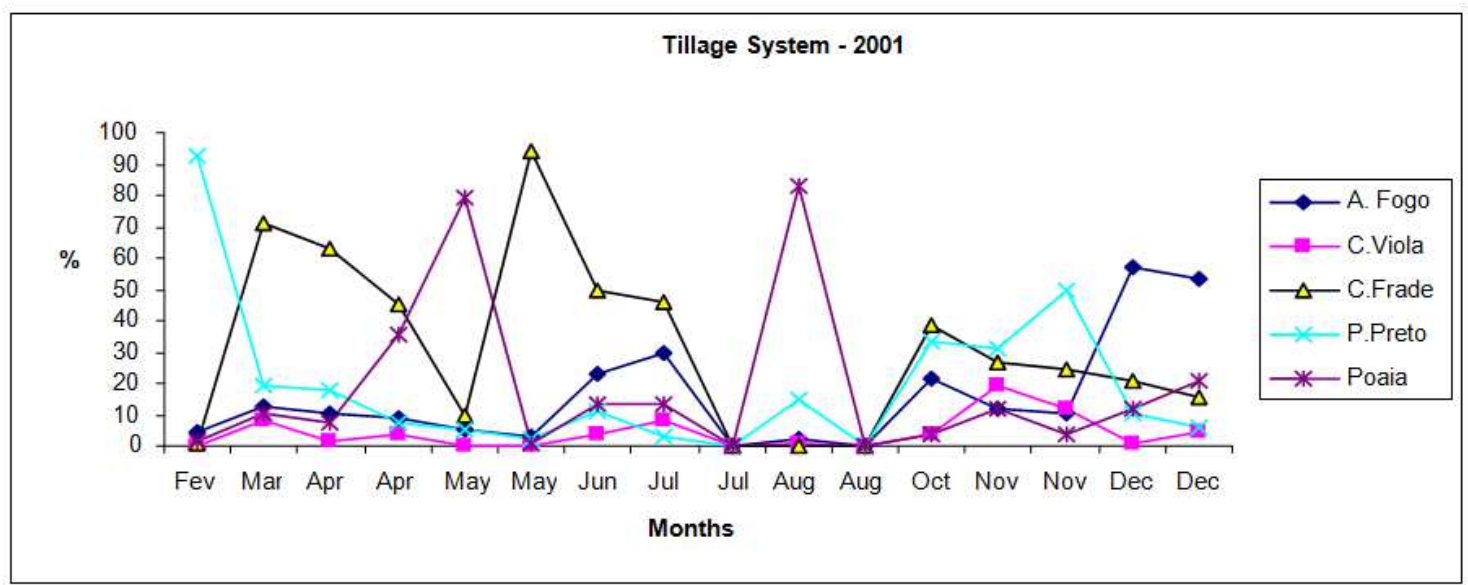

Figure 5. Emergency percentage (\%) of broadleaved species Alternanthera tenella, Ipomoea grandifolia, Leucas martinicensis, Bidens pilosa and Richardia brasiliensis from January to December 2001 in tillage system.

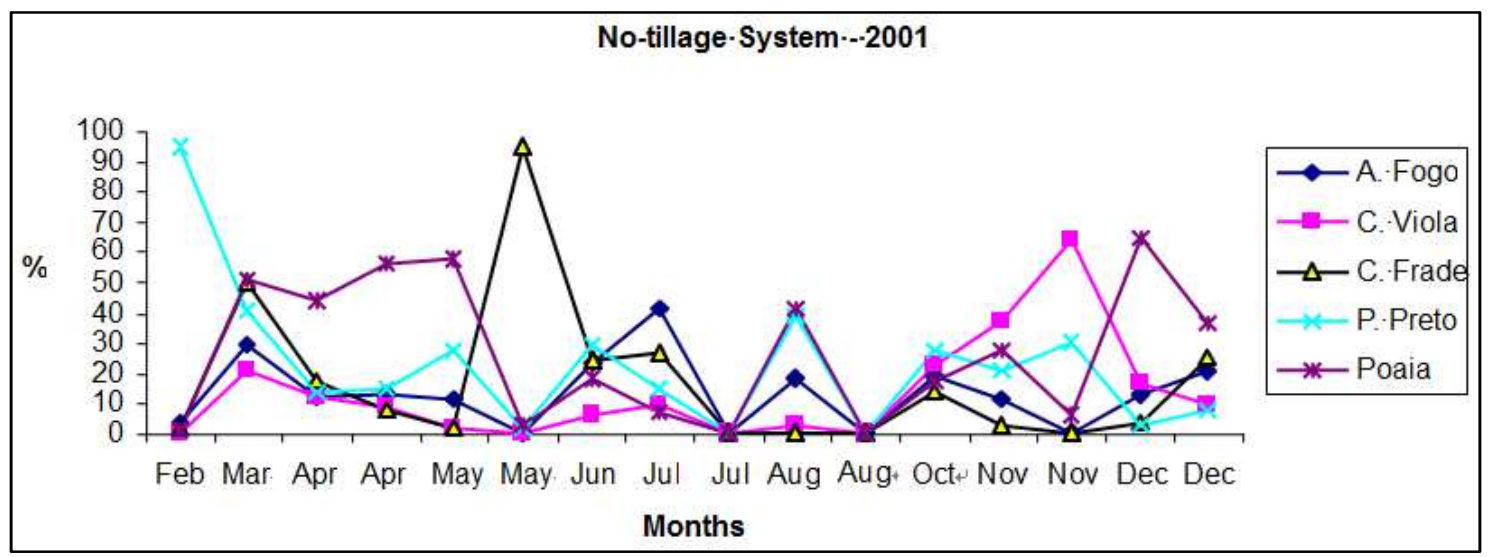

Figure 6. Emergency percentage (\%) of broadleaved species Alternanthera tenella, Ipomoea grandifolia, Leucas martinicensis, Bidens pilosa and Richardia brasiliensis from January to December 2001 in no-tillage system.

Analysis of variance among weed emergence, at different soil depths and between direct and conventional sowing systems, lies in Table 4 and it shows that there was a significant difference referring the sowing systems, soil depths and system interaction.

Table 4. Analysis of data variance of weed emergence at different depths, in direct and conventional planting systems, after 15, 30 and 60 days of trays installation inside a greenhouse.

\begin{tabular}{lllll}
\hline Variation Causes & GL & 15 days & 30 days & 60 days \\
\hline Systems (S) & 1 & $3.43^{\text {ns }}$ & $266.17^{* *}$ & $19.03^{\text {ns }}$ \\
Depht $(\mathrm{P})$ & 4 & $177.27^{* *}$ & $21.90^{\mathrm{ns}}$ & $42.50 * *$ \\
S*P & 4 & $552.31^{* *}$ & $326.34^{* *}$ & $137.38^{* *}$ \\
Residue & 270 & 41.27 & 17.58 & 11.25 \\
\hline
\end{tabular}

* Significant difference at $5 \%$ probability by Test $\mathrm{F}$

** Significant difference at $1 \%$ probability by Test $\mathrm{F}$

Through deploying any interaction between depth and system it was found significant difference, after 15 days of soil remaining in a greenhouse for counting, in the number of emerged plants per tray in depths, $5.0-10.0$ and 15.0 $20.0 \mathrm{~cm}$. In no-tillage systems there was a greater quantity of emergence plants at $2.5-5.0 \mathrm{~cm}$ deep. Depths of 5.0 -
10.0 and $15.0-20.0 \mathrm{~cm}$ showed a greater amount of emerged plants for the conventional system. In depths of $0.0-2.5$ and $10.0-15.0 \mathrm{~cm}$ there was no significant difference.

In Table 6, the data show the same trend as in Table 5, showing that occurred, at 30 days, the greatest emergence of weeds in the upper layers of soil treated with till system. In the layer $2.5-5.0 \mathrm{~cm}$ deep, the use of no tillage was significantly different at $5 \%$ of conventional seeding system, while the layers of 5.0-10.0 and $15.0-20.0 \mathrm{~cm}$ deep, occurred the most significant emergence plant in the conventional system. Again there was no significant difference in the depths of $0.0-2.5$ and 10.0-15.

Table 5. Breakdown of weeds emerged in direct seeding and conventional systems 15 days after the trays placed at home in vegetation ${ }^{l}$.

\begin{tabular}{llllll}
\hline \multirow{2}{*}{ Systems } & \multicolumn{5}{l}{ Depht (cm) } \\
\cline { 2 - 6 } & $\mathbf{0 - 2 . 5}$ & $\mathbf{2 . 5 - 5 . 0}$ & $\mathbf{5 . 0 - 1 0 . 0}$ & $\mathbf{1 0 . 0 - 1 5 . 0}$ & $\mathbf{1 5 . 0 - 2 0 . 0}$ \\
\hline Tillage & 10.6 & $11.1 \mathrm{a}$ & $8.1 \mathrm{~b}$ & 10.6 & $7.4 \mathrm{~b}$ \\
No tillage & 10.1 & $2.3 \mathrm{~b}$ & $11.5 \mathrm{a}$ & 9.5 & $15.6 \mathrm{a}$ \\
\hline
\end{tabular}

${ }^{1}$ Means followed by the same letter in the column do not differ statistically by Tukey test at $5 \%$ probability 
Table 6. Breakdown of emerged weeds in direct seeding and conventional systems, 30 days after trays being placed at home vegetation ${ }^{l}$.

\begin{tabular}{llllll}
\hline \multirow{2}{*}{ Systems } & \multicolumn{5}{l}{ Depht $(\mathbf{c m})$} \\
\cline { 2 - 6 } & $\mathbf{0 - 2 . 5}$ & $\mathbf{2 . 5 - 5 . 0}$ & $\mathbf{5 . 0 - 1 0 . 0}$ & $\mathbf{1 0 . 0 - 1 5 . 0}$ & $\mathbf{1 5 . 0 - 2 0 . 0}$ \\
\hline Tillage & 2.5 & $5.1 \mathrm{a}$ & $0.85 \mathrm{~b}$ & 4.5 & $0.4 \mathrm{~b}$ \\
No tillage & 4.5 & $1.1 \mathrm{~b}$ & $5.3 \mathrm{a}$ & 3.3 & $8.8 \mathrm{a}$ \\
\hline
\end{tabular}

${ }^{1}$ Means followed by the same letter in the column do not differ statistically by Tukey test at $5 \%$ probability.

In the third evaluation (Table 7), the conventional system caused a 4.3 times greater seedling emergence at 15.0-20.0 $\mathrm{cm}$ deep, when compared to the direct system. The direct seeding system showed better weed emergence at $2.5-5.0 \mathrm{~cm}$ deep. The values of 4.6 and 1.6 for direct and conventional system, respectively, were statistically different at $5 \%$ probability.

Tabela 7. Number of weeds emerged in no-tillage and conventional tillage systems at 60 days after trays placed under greenhouse ${ }^{l}$.

\begin{tabular}{llllll}
\hline \multirow{2}{*}{ Systems } & \multicolumn{5}{l}{ Depht $(\mathbf{c m})$} \\
\cline { 2 - 6 } & $\mathbf{0 - 2 , 5}$ & $\mathbf{2 , 5 - 5 , 0}$ & $\mathbf{5 , 0 - 1 0 , 0}$ & $\mathbf{1 0 , 0 - 1 5 , 0}$ & $\mathbf{1 5 , 0 - 2 0 , 0}$ \\
\hline Tillage & 5,5 & $4,6 \mathrm{a}$ & 3,8 & 5,4 & $1,6 \mathrm{~b}$ \\
No tillage & 4,9 & $1,6 \mathrm{~b}$ & 5,0 & 4,9 & $7,0 \mathrm{a}$ \\
\hline
\end{tabular}

${ }^{1}$ Means followed by the same letter in the column do not differ statistically by Tukey test at $5 \%$ probability

Weed emergence comparison at different depths in conventional factor are shown in Tables 8 and 9 , data is related to 15,30 and 60 days after placement of the trays in the greenhouse for emergence testing. It was verified in conventional system that there was a greater emergence in the depths of $0.0-2.5 ; 5.0-10.0 ; 10.0-15.0 ; 15.0-20.0 \mathrm{~cm}$. The values found in this soil depth were not higher than three seedling per tray. Found that seeds concentrated at $2.5 \mathrm{~cm}$ deep in direct system, while the conventional preparation distributed seeds at $20 \mathrm{~cm}$ deep [7].

Tabela 8. Average of 28 repetitions of the number of weeds emerged at different soil depths sampled at 15, 30 and 60 days after trays placed at home under conventional sowing vegetation ${ }^{l}$.

\begin{tabular}{llll}
\hline Depht $(\mathbf{c m})$ & $\mathbf{1 5}$ days & 30 days & 60 days \\
\hline $0-2,5$ & $10,1 \mathrm{a}$ & $4,5 \mathrm{a}$ & $4,9 \mathrm{a}$ \\
$2,5-5,0$ & $2,3 \mathrm{c}$ & $1,1 \mathrm{c}$ & $1,6 \mathrm{~b}$ \\
$5,0-10,0$ & $11,5 \mathrm{ab}$ & $5,4 \mathrm{~b}$ & $5,0 \mathrm{a}$ \\
$10,0-15,0$ & $9,5 \mathrm{~b}$ & $3,3 \mathrm{bc}$ & $4,9 \mathrm{a}$ \\
$15,0-20,0$ & $15,6 \mathrm{a}$ & $8,8 \mathrm{a}$ & $7,1 \mathrm{a}$ \\
\hline
\end{tabular}

${ }^{1}$ Means followed by the same letter in the column do not differ statistically by Tukey test at $5 \%$ probability

The average number of weeds emerged in the tillage system, after 15, 30 and 60 days, is shown in Table 9. Note that after 15 days there was no difference between depths, however in 30 and 60 days a significant difference appeared in depth of 15.0-20.0 cm, representing fewer emerged seedlings with values of 0.4 and 1.6 , respectively.

Tabela 9. Average 28 repetitions of the number of weeds emerged at 15, 30 and 60 days after trays placed at home in vegetation at different soil depths sampled in no-till systems ${ }^{l}$.

\begin{tabular}{lcc}
\hline Depht $(\mathbf{c m})$ & 30 days & 60 days \\
\hline $0-2,5$ & $2,5 \mathrm{ab}$ & $5,5 \mathrm{a}$ \\
$2,5-5,0$ & $5,1 \mathrm{a}$ & $4,6 \mathrm{a}$ \\
$5,0-10,0$ & $0,9 \mathrm{~b}$ & $3,8 \mathrm{ab}$ \\
$10,0-15,0$ & $4,5 \mathrm{a}$ & $5,4 \mathrm{a}$ \\
$15,0-20,0$ & $0,4 \mathrm{~b}$ & $1,6 \mathrm{~b}$ \\
\hline
\end{tabular}

${ }^{1}$ Means followed by the same letter in the column do not differ statistically by Tukey test at $5 \%$ probability

No-till or shallow tillage results in seeds concentrated near soil surface. Due to soil disturbance occurred by the use of plow and grade, in the conventional system, made the existing seeds in the area to be displaced to the lower depths. The tillage system presented no disturbance at any time allowing seeds to remain leveled at soil surface.

Mentions that relatively few invasive species can emerge at depths greater than $5 \mathrm{~cm}$, except for species with large seeds [3]. Although these species germinate, they cannot emerge as said by [5]. studying the no-tillage system, found that more than $60 \%$ of all weed seeds were found within $1 \mathrm{~cm}$ of the soil surface and few seeds were found below $10 \mathrm{~cm}$ [11]. Also found more than $60 \%$ of the bank concentrates seeds at a depth of up to $5 \mathrm{~cm}$ in soils with minimum tillage or fallow [4].

Studying efectiveness of application of different rates in Bidens pilosa (L.), Commelina benghalensis (L.), Digitaria insularis L. (Fedde), Ipomoea grandiofolia (L.) e Tridax procumbens $(L$.$) It was concluded that the herbicide$ glyphosate controlled $B$. pilosa and D. insularis, occurring control of $100 \%$ of these species in $14 \mathrm{DAA}$ in the rate of 720 g.i.a ha ${ }^{-1} C$. benghalensis was considered a specie of difficult control. The necessary rate to reach control indexes above $91 \%$ was of 1680 g.i.a ha ${ }^{-1}$ for C. benghalensis, 960 g.i.a ha ${ }^{-1}$ in the species $T$. procumbens and 1440 g.i.a ha ${ }^{-1}$. of glyphosate for I. grandifolia in 21 DAA [8].

\section{Conclusions}

Glyphosate is an effective substance for controlling existing weeds in the area in doses of 540 g.i.a ha $^{-1}$ In the year of 2001 they happened flows of Leucas martinensis Jacq., Richardia brasilensis Gomes, Cenchrus echinatus L. and would Type insularis (Feed) L in a way more differentiated in the no tillage than in the tillage. In the year of 2002 those differences of flows of the species, were not as expressive as in 2001.

In the no tillage system, the seeds concentrated on the surface of the soil, while the tillage preparation to they distributed them in larger depths. 


\section{Appendix}

Table A1. It lists of the species, family and common name of the dicotiledoneas found in the experimental areas during the years of studies in the system of tillage and no tillage.

\begin{tabular}{|c|c|c|}
\hline Species & Families & Common name \\
\hline \multicolumn{3}{|l|}{ Dicotiledoneas } \\
\hline Acanthospermum hispidum DC. [ACNHI] & Compositae & Carrapicho de Carneiro \\
\hline Ageratum conyzoides $\mathrm{L} .[\mathrm{AGECO}]$ & Compositae & Mentrasto \\
\hline Alaternanthera tenella Colla [ALRTE] & Amaranthaceae & Apaga Fogo \\
\hline Amaranthus viridis L. [AMAVI] & Amaranthaceae & Caruru \\
\hline Bidens pilosa L. [BIDPI] & Compositae & Picão Preto \\
\hline Blainvillea SP & Compositae & Erva Palha \\
\hline Chamaesyce hirta L. (Milisp.) [EPHHI] & Euphorbiaceae & Erva de Santa Luzia \\
\hline Coronopus didymus L. (Sm.) [COPDI] & Cruciferae & Mentruz \\
\hline Desmodium sp & Leguminosae & Beiço de Boi \\
\hline Emilia sonchifolia L. [EMISO] & Compositae & Falsa Serralha \\
\hline Euphorbia heterophylla L. [EPHHL] & Euphorbiaceae & Leiteiro \\
\hline Galinsoga parviflora Cav. [GASPA] & Compositae & Picão Branco \\
\hline Ipomoea grandifolia Dammer [IAOGR] & Convolvulaceae & Corda de Viola \\
\hline Leucas martinicensis Jacq. [LEUMA] & Labiatae & Falso Cordão de Frade \\
\hline Mimosa invisa Mart ex. Colla [MIMIN] & Leguminosae & Anileira \\
\hline Oxalis latifolia Kunth [OXALA] & Oxalidaceae & Trevo \\
\hline Parthenium hysterophorus L. [PTNHY] & Compositae & Losna Branca \\
\hline Richardia brasiliensis Gomes [RCHBR] & Rubiaceae & Poaia \\
\hline Senna obtusifolia L. [CASOB] & Leguminosae & Fedegoso \\
\hline Sonchus oleraceus L. [SONOL] & Compositae & Serralha Verdadeira \\
\hline Xantium strumarium L. [XANSI] & Compositae & Carrapichão \\
\hline
\end{tabular}

Table A2. It lists of the species, family and common name of the monocotiedoneas found in the experimental areas during the years of studies in the system of tillage and no tillage.

\begin{tabular}{lll}
\hline Species & Families & Common name \\
\hline Monocotiledoneas & & Capim Carrapicho \\
\hline Cenchrus echinatus L. [CCHEC] & Gramineae & Trapoeraba \\
Commelina benghalensis L. [COMBE] & Commelinaceae & Capim Colchão \\
Digitaria ciliaris Retz. (Koel) [DIGSP] & Gramineae & Capim Amargoso \\
Digitaria insularis L. (Feed) [TRCIN] & Gramineae & Capim Pé de Galinha \\
Eleusine indica L. [ELEIN] & Gramineae & Capim Colonião \\
Panicum maximum Jacq. [PANMA] & Gramineae & Capim Massambará \\
Sorghum halepense L. (Pers.) [SORHA] & Gramineae & \\
\hline
\end{tabular}

Table A3. Daily meteorological data for the month of May 2001 collected at ESALQ / USP.

\begin{tabular}{|c|c|c|c|c|c|c|}
\hline \multirow{3}{*}{ DIA } & INSOLACAO & PRECIPITACAO & UMID. & TEMP. & TEMP. & TEMP. \\
\hline & \multirow{2}{*}{$\mathbf{h} / \mathbf{d}$} & \multirow{2}{*}{$\mathbf{m m}$} & RELATIVA & MAX. & MIN. & MEDIA \\
\hline & & & $\%$ & ${ }^{\circ} \mathrm{C}$ & ${ }^{\circ} \mathrm{C}$ & ${ }^{\circ} \mathrm{C}$ \\
\hline 1 & 9.1 & 0.0 & 67 & 30.6 & 15.8 & 23.2 \\
\hline 2 & 8.8 & 0.0 & 66 & 32.5 & 17.0 & 24.8 \\
\hline 3 & 9.1 & 0.0 & 66 & 32.6 & 17.5 & 25.1 \\
\hline 4 & 5.4 & 7.7 & 79 & 30.7 & 17.1 & 23.9 \\
\hline 5 & 9.6 & 0.0 & 53 & 21.6 & 10.5 & 16.1 \\
\hline 6 & 10.3 & 0.0 & 66 & 22.6 & 6.9 & 14.8 \\
\hline 7 & 9.7 & 0.0 & 73 & 24.3 & 8.3 & 16.3 \\
\hline 8 & 7.6 & 0.0 & 75 & 25.4 & 10.2 & 17.8 \\
\hline 9 & 9.0 & 0.0 & 73 & 28.4 & 9.0 & 18.7 \\
\hline 10 & 7.8 & 0.0 & 63 & 31.0 & 12.2 & 21.6 \\
\hline 11 & 1.0 & 6.5 & 89 & 25.1 & 16.7 & 20.9 \\
\hline 12 & 3.6 & 2.3 & 87 & 25.3 & 17.4 & 21.4 \\
\hline 13 & 3.3 & 21.7 & 88 & 23.6 & 15.8 & 19.7 \\
\hline 14 & 3.4 & 0.0 & 83 & 21.3 & 14.0 & 17.7 \\
\hline 15 & 4.8 & 0.0 & 79 & 24.2 & 11.2 & 17.7 \\
\hline 16 & 0.5 & 11.2 & 99 & 17.9 & 12.9 & 15.4 \\
\hline 17 & 3.8 & 1.7 & 85 & 22.1 & 14.4 & 18.3 \\
\hline 18 & 9.5 & 0.0 & 71 & 21.6 & 7.0 & 14.3 \\
\hline 19 & 6.9 & 0.0 & 77 & 21.7 & 7.8 & 14.8 \\
\hline 20 & 8.8 & 0.0 & 73 & 25.0 & 8.9 & 17.0 \\
\hline 21 & 7.7 & 0.0 & 74 & 26.5 & 10.8 & 18.7 \\
\hline
\end{tabular}




\begin{tabular}{|c|c|c|c|c|c|c|}
\hline \multirow{3}{*}{ DIA } & \multicolumn{2}{|r|}{ PRECIPITACAO } & \multirow{2}{*}{$\begin{array}{l}\text { UMID. } \\
\text { RELATIVA }\end{array}$} & \multirow{2}{*}{$\begin{array}{l}\text { TEMP. } \\
\text { MAX. }\end{array}$} & \multirow{2}{*}{$\begin{array}{l}\text { TEMP. } \\
\text { MIN. }\end{array}$} & \multirow{2}{*}{$\begin{array}{l}\text { TEMP. } \\
\text { MEDIA }\end{array}$} \\
\hline & \multirow{2}{*}{ h/d } & \multirow{2}{*}{$\mathbf{m m}$} & & & & \\
\hline & & & $\%$ & ${ }^{\circ} \mathbf{C}$ & ${ }^{\circ} \mathbf{C}$ & ${ }^{\circ} \mathbf{C}$ \\
\hline 22 & 0.6 & 0.0 & 86 & 21.9 & 10.4 & 16.2 \\
\hline 23 & 4.6 & 0.0 & 82 & 24.4 & 12.4 & 18.4 \\
\hline 24 & 7.1 & 0.0 & 78 & 26.5 & 12.5 & 19.5 \\
\hline 25 & 4.0 & 0.0 & 83 & 24.2 & 12.3 & 18.3 \\
\hline 26 & 5.7 & 0.0 & 78 & 26.5 & 12.8 & 19.7 \\
\hline 27 & 3.0 & 7.3 & 99 & 20.2 & 16.2 & 18.2 \\
\hline 28 & 3.4 & 0.0 & 92 & 25.3 & 16.3 & 20.8 \\
\hline 29 & 7.4 & 2.2 & 85 & 27.5 & 17.1 & 22.3 \\
\hline 30 & 8.3 & 0.0 & 77 & 29.4 & 14.0 & 21.7 \\
\hline 31 & 6.0 & 0.0 & 83 & 28.6 & 12.8 & 20.7 \\
\hline \multicolumn{2}{|c|}{ MEDIA } & 2.0 & 78 & 25.4 & 12.8 & 19.1 \\
\hline \multicolumn{2}{|c|}{ TOTAL } & 60.6 & 2429 & 788.5 & 398.2 & 593.4 \\
\hline \multicolumn{2}{|c|}{ DESVIO PADRAO } & 4,6 & 10 & 3.7 & 3.3 & 2.9 \\
\hline \multicolumn{2}{|c|}{ VARIANCIA } & 20.8 & 103 & 13.4 & 10.6 & 8.4 \\
\hline \multicolumn{2}{|c|}{ VALOR MAXIMO } & 21,7 & 99 & 32.6 & 17.5 & 25.1 \\
\hline \multicolumn{2}{|c|}{ VALOR MINIMO } & 0,0 & 53 & 17.9 & 6.9 & 14.3 \\
\hline \multicolumn{2}{|c|}{ DIAS DE HUVA: } & 8 & & & & \\
\hline
\end{tabular}

\section{References}

[1] BALL, D. A. Weed seedbank response to tillage, herbicides, and crop rotation sequence. Weed Science, v. 14, p. 654-659, 1992.

[2] CARDINA, J.; REGNIER, E.; HARRISON, K. Long-term tillage effects on seed banks in three Ohio soils. Weed Science, v. 39, p. 186-194, 1991.

[3] CARMONA, R. Problemática e manejo de bancos de sementes de invasoras em solos agrícolas. Planta Daninha, v. 10, n. 1/2, p. 5-16, 1992.

[4] CLEMENTS, D. R.; BENOIT, D. L.; MURPHY, S. D.; SWANTON, C. J. Tillage effects on weed seed return and seedbank composition. Weed Science, v. 44, p. 314-322, 1996.

[5] FROUD-WILLIAMS, R. J.; CHANCELLOR, R. J.; DRENNAN, D. S. H. Influence of cultivation regime upon burid weed seed in arable cropping systems. Journal of Applied Ecology, v. 20, p. 199-208, 1983.

[6] HOFFMAN, M. L.; OWEN, M. D. K.; BUHLER, D. D. Effects of crop and weed management on density and vertical distribution of weed seeds in soil. Agronomy Journal, v. 90, p. 793-799, 1998.

[7] SCHREIBER, M. M.; Influences of tillage, crop rotation, and weed management on giant foxtaie (Setaria faberi) population dynamics and corn yield. Weed Science, v. 40, p. 645-653, 1992.

[8] LACERDA, A. L. S.; VICTORIA, R.; SOUZA, Z. M.; TORRES, J. L. R. Use of different doses of glyphosate to control invasive plants: Bidens pilosa, Commelina benghalensis, Digitaria insularis, Ipomoea grandiofolia and Tridax procumben. Australian Journal Crop Science, v. 13, n. 04, p. 529-535, 2019.

[9] PITELLI, R. A. Dynamics of weeds in tillage. In: SYMPOSIUM ON HERBICIDES AND WEED, Golden, 1997. Proceedings. Golden: EMBRAPA, CPAO, 1997. p. 5061 .

[10] ROBERTS, H. A. Seed banks in the soil. Cambridge: Academic Press, 1981. 55p. (Advances in Applied Biology, 6).

[11] YENISH, J. P.; DOLL, J. D.; BUHLER, D. D. Effects of tillage on vertical distribution and viability of weed seed in soil. Weed science, v. 40, p. 429-433, 1992. 